\title{
The Effect of Religiosity on Product Involvement in a Muslim Society
}

\author{
Dursun YENER \\ Beykoz Lojistik Meslek Yüksekokulu \\ Vatan Caddesi, Beykoz, İstanbul, Türkiye \\ dursunyener@yahoo.com
}

\begin{abstract}
Religion has an important place in social life. It does not only affect the structure of society by shaping behavior and attitudes of people but also is affected from the social construct. Since religion has been perceived as a taboo subject, the number of researches about the relationship between religiosity and marketing are limited. Most of existing papers is relevant to Christianity and other religions. This study aims to present the effect of religiosity on product involvement using Allport's intrinsic/extrinsic religious orientation scale (ROS) in a Muslim sample. Three different product categories were selected (food, cosmetics and cleaning products) to analyze. Sample size of the research is 282 people which were selected by convenience sampling method. In methodology part, correlation and regression analyses and ANOVA and independent sample t-test were used. As a result, participants' level of involvement for each product group is differentiated according to their religiosity orientation. Since the scale was applied on a Muslim sample in Turkey, the study is also important.
\end{abstract}

Keywords: Religious Orientation, Product Involvement, Behavior of Customer, Attitude of Purchase.

\section{Introduction}

Religion has an important place in social life. It does not affect only the structure of society by shaping behavior and attitudes of people but also is affected from the social construct. Religions cannot be strictly distinguished from daily, social and economic activities (Saeed, Ahmed and Mukhtar, 2001, p.127). Studies about measuring the religiosity started in 1940s. Many of these studies are about Christian religiosity (Onay, 2004, p.43). There is not a consensus about the dimensions of religiosity (Mokhlis, 2009, p.77).

Involvement is another important concept in marketing area. It can be defined as a person's perceived relevance of the object based on inherent needs, values and interests (Zaichkowsky, 1985, p.342). Product involvement has received considerable attention 
from consumer researchers because it influences consumer's cognitive and behavioral responses to marketing stimuli. It is defined as "an internal state variable that indicates the amount of arousal, interest or drive evoked by a product class" (Dholakia, 2000, p.1341).

Involvement level about a product is affected from many factors. One of the most important factors that affect involvement level is religion. Since religion is a frame that covers a person's whole life, its effects can be seen in all consumer activities. However religiosity level of all people is different from each other, so religions' effects about involvement toward products are different too. The purpose of this study is to show the relationship between religiosity and involvement concept in Turkey where its population consists of Muslim people (99\% of all population).

\section{Religiosity}

Religion is a system of beliefs about the supernatural and spiritual world, about God, and about how humans, as God's creatures, are supposed to behave on this earth (Sheth and Mittal, 2004, p.65).

One function of religion is to provide a source of meaning and purpose for people. Religion can provide a framework which makes life understandable and interpretable (Delener, 1994, p.36; Vitell, Paolillo and Singh, 2005, p.175). It is a complex subject to understand the effects of religions on human behaviors. So the studies have focused on the effect of the degree of commitment in religion on behaviors (Muhamad and Mizerski, 2010, p.125). Religion is a universal construct that have an impact on people's attitudes, values and behaviors (Mokhlis, 2009, p.75).

The studies in sociology or psychology discipline focus on the religion, but its role in consumer research has not sufficiently been dealt with. The role of religion on society's values and role of these values on consumer behavior cannot be underestimated (Essoo and Dibb, 2004, p.683). Although religion has always been a cultural element in consumer behavior framework, religion and its influence has long been perceived as a taboo subject matter for investigation in marketing areas (Muhamad and Mizerski, 2010, p.124).

The effect of religion in consumer behavior has not attracted enough attention. Cutler (1991) analyzed 7000 journals published between 1959 and 1989 and only 35 articles are related with the subject. 6 of these articles are included in consumer behavior discipline (Lindridge, 2005, p.142).

In marketing literature, religion is thought as a factor that affects consumer behaviors and purchasing decisions (Essoo and Dibb, 2004, p.684; Muhamad and Mizerski, 2010, p.124; Lindridge, 2005, p.142; Delener, 1990, p.27). Religiosity of people is used as a market segmentation technique by marketers (Swimberghe, Sharma and Flurry, 2009, p.340). No religion can be separated completely from people's daily, social and commercial activities (Saeed, Ahmed and Mukhtar, 2001, p.127).

While working on religiosity, the most important problem is to develop instruments which will measure the variables accurately. Some researchers have claimed that religiosity is one-dimensional and others claim it is multi-dimensional. As a result, several measurements have emerged. There is a vast number of existing measures of religion created and/or used in psychology research. In their edited book on religious instruments, Hill and Hood (1999) compiled 125 measures of religiosity and 
spirituality (King and Crowther, 2004, pp.85-6). There have been numerous approaches to religiousness; however, no approach has had such a great impact as Allport's approach. According to Allport, religious phenomena are multidimensional and he distinguished two types of religious orientation which are intrinsic and extrinsic. Extrinsically motivated person uses his/her religion for their own ends, and their values are instrumental. Intrinsically motivated person lives his/her religion (Allport and Ross, 1967, p.434). Prejudice and extrinsic religious orientation are positively correlated while prejudice and intrinsic religious orientation are negatively correlated (Allport and Ross, 1967, p.441). Essoo and Dibb (2004) found that the extrinsically religious consumers were trendier, innovative and more demanding. On the other hand the intrinsically religious followers were more conservative, traditional, and insightful and mature (Muhamad and Mizerski, 2010, p.129).

While the "religious orientation scale" has proven to have acceptable reliability, and has shown some indication of applicability for marketing and consumer behavior disciplines (Delener, 1990; Essoo and Dibb, 2004), the inventory has a shortcoming. It was designed to be used with Christian subjects (Mokhlis, 2009, p.77). The role of religiousness on consumer researches was not held accurately. The effect of religion in consumer behavior discipline can show differences from culture to culture (Mokhlis, 2006, p.66).

\section{Involvement}

Involvement is considered as an individual difference variable. It is a motivating variable with a number of consequences on the consumer's purchase and communication behavior (Laurent and Kapferer, 1985, p.42).

The concept of consumer involvement has received widespread attention in the marketing discipline over the last 30 years. Consumer involvement is rooted in the Allport (1943) and Sherif and Cantril's (1947) seminal treatments of ego involvement (Broderick, 2007, p.345). Sherif and Cantril (1947), in their work titled "The Psychology of Ego Involvement" pioneered the academic research on involvement (George and Edward, 2009, p.8; Laurent and Kapferer, 1985, p.42).

It is difficult to find a single definition for the involvement concept. Involvement is defined by Zaichkowsky (1985, p.345) as a person's perceived relevance of the object based on inherent needs, values and interests.

Involvement of the consumer can be thought as the degree of showing consideration for the desired purchasing product based on inherent needs, values and interests consumers with different levels of involvement, would carry out different consumer behavior if the involvement is low, consumers often resort to buying one of the brands they know and like (Blackwell, Miniard and Engel, 2006, p.150). Depending on their level of involvement, individual consumers differ in the extent of their decision process and their search for information (Laurent and Kapferer, 1985, p.41). Depending on their involvement level, consumers may be passive or active. Consumers who are highly involved spend more time to get information because they evaluate more resources (Assael, 1998, p.147).

\section{Involvement Types}


Houston and Rothschild make a distinction for the involvement concept (Laurent and Kapferer, 1985, p.42; Michaelidou and Dibb, 2008, p.86). According to this concept, distinction involvement can be evaluated as;

- Situational involvement

-Enduring involvement

Situational involvement is defined as the degree to which a consumer is motivated to avoid the negative outcomes of product purchase; therefore, it captures a consumer's concern with avoiding a bad buy or making a sub-optimal choice. It is a temporary phenomenon that occurs when a consumer is contemplating purchase (Venkatraman, 1989, p.230). According to Richins and Bloch (1986), this concern does not disappear immediately after purchase but continues for the period over which the consumer is trying to resolve cognitive dissonance.

Enduring involvement is defined as the long-term and ongoing concerns with products that are motivated by the enjoyment or pleasure a consumer derives from it and/or by the desire for knowledge and expertise about the product. According to Houston and Rothshild (1978), enduring involvement captures a relationship between an individual and a product that exists independently of a specific purchase situation (Venkatraman, 1989, p.231). As the degree of enduring involvement increases, searching and sharing information efforts of people will also rise (Higgie and Feick 1989, p.695).

Zaichkowsky (1986, p.6) also made a classification about involvement. She divided it into three categories. These are advertisement, product and purchasing involvement. Product involvement is defined as "an internal state variable that indicates the amount of arousal, interest or drive evoked by a product class", which is consistent with definitions of other consumer psychologists (Dholakia, 2000, p.1341). A product can be important for consumers but this does not require for them to have enduring involvement to this product (Mittal, 1989, p.148).

\section{Research Methodology}

The research population of the study is consumers who live in Istanbul. Convenience sampling method was used to gather data. All respondents are Muslim, older than 18 years old and live in Istanbul. Data was obtained using a questionnaire which contains close-ended questions with face-to-face method. For measuring religiosity, Allport and Ross's Religious Orientation Scale (ROS) were used. This scale has two parts as extrinsic and intrinsic religious orientation and consists of 21 questions in 5-point Likert form. For involvement, Zaichkowsky's Revised Personal Involvement Inventory scale was used for three different product categories which are food, cleaning and cosmetics products. This scale has 10 items and these items are in 7-point semantic differentials form. 282 people have participated the study. Demographic profiles of the respondents are shown in Table 1.

Upon analysis of the research study, there are some limitations that may become future areas of research that could be used to make progress with this subject. First, the size of the selected samples is small and they live in one city of Turkey. It would be useful to repeat the study with larger and geographically more diversified samples, so that the opinions of other demographic groups could be taken into account. Second, this research focuses only on religiosity on product involvement of consumers toward 
selected product categories. However, involvement concept has different dimensions and consumers' attitudes about these subjects should also be determined.

Table 1: Demographic Characteristics of the Respondents

\begin{tabular}{|l|lr|}
\hline Gender & Male & $62 \%$ \\
\hline \multirow{3}{*}{ Age } & Female & $38 \%$ \\
\hline \multirow{2}{*}{ Marital Status } & $18-30$ & $48 \%$ \\
& $31-40$ & $34 \%$ \\
Education Level & $41+$ & $18 \%$ \\
\hline \multirow{3}{*}{ Monthly Household Income } & Single & $42 \%$ \\
& Married & $58 \%$ \\
\hline & Primary & $6 \%$ \\
& High school & $34 \%$ \\
Occupation & Undergraduate & $47 \%$ \\
& Graduate & $13 \%$ \\
\hline & $0-1000$ TL & $15 \%$ \\
& $1001-2000$ TL & $43 \%$ \\
& 2001-3000 TL & $23 \%$ \\
& 3001+ TL & $19 \%$ \\
\hline
\end{tabular}

In Figure 1, the research model is seen. According to this model, five research hypotheses can be generated. These hypotheses can be seen in Table 2

Table 2: Research Questions

\begin{tabular}{|l|l|}
\hline $\mathrm{H}_{1}$ & $\begin{array}{l}\text { There is a significant relationship between intrinsic religiosity and product } \\
\text { involvement. }\end{array}$ \\
\hline $\mathrm{H}_{2}$ & $\begin{array}{l}\text { There is a significant relationship between extrinsic religiosity and product } \\
\text { involvement. }\end{array}$ \\
\hline $\mathrm{H}_{3}$ & $\begin{array}{l}\text { There is a significant relationship between demographic factors and product } \\
\text { involvement. }\end{array}$ \\
\hline $\mathrm{H}_{4}$ & $\begin{array}{l}\text { There is a significant relationship between demographic factors and intrinsic } \\
\text { religiosity. }\end{array}$ \\
\hline $\mathrm{H}_{5}$ & $\begin{array}{l}\text { There is a significant relationship between demographic factors and extrinsic } \\
\text { religiosity. }\end{array}$ \\
\hline
\end{tabular}




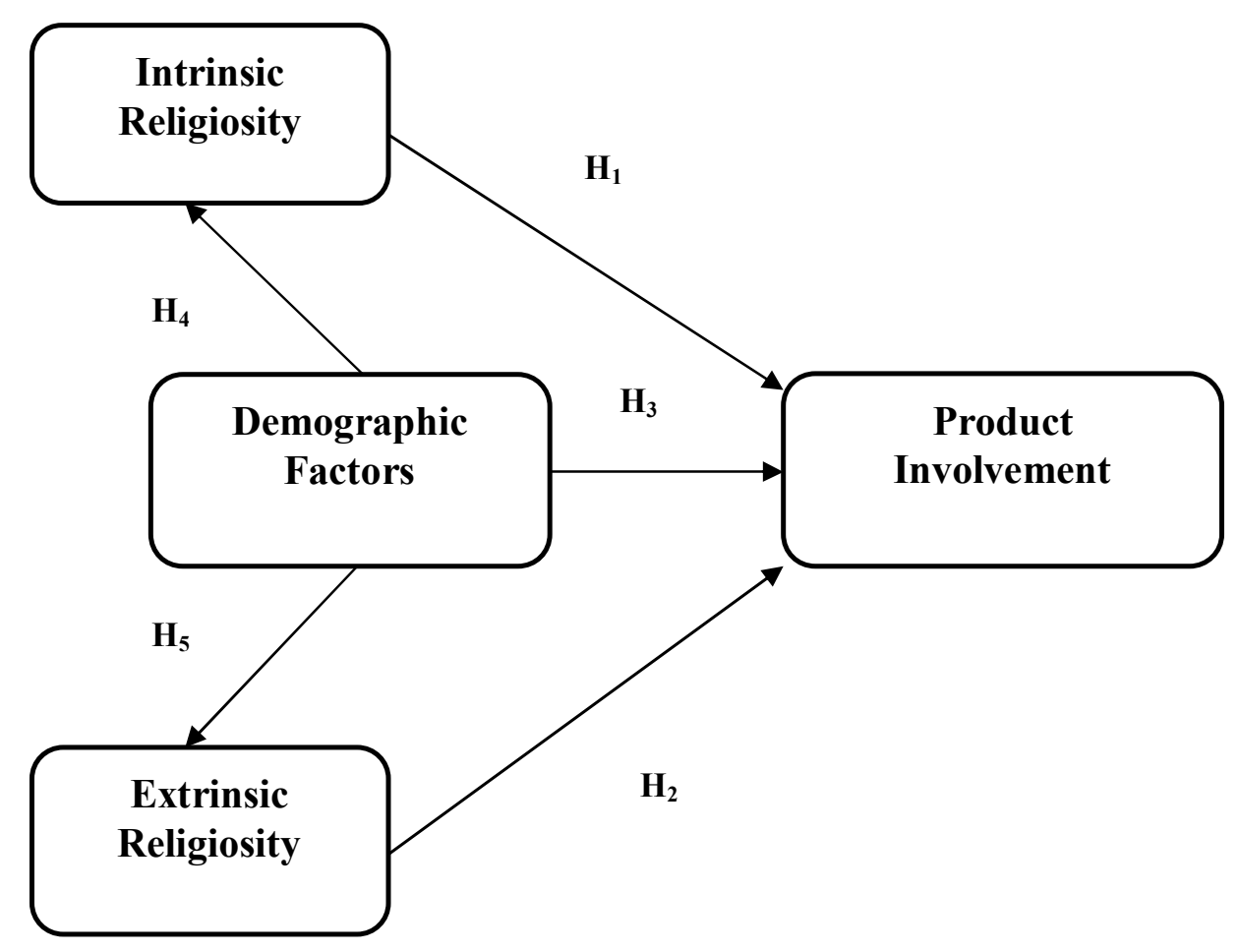

Figure 1: Research Model

\section{Findings}

Mean and standard deviation values about involvement level according to the three product categories are seen in Table 3.

Table 3: Descriptive Statistics about Product Involvement

\begin{tabular}{|l|c|c|}
\hline & Mean & Std. Deviation \\
\hline Food Products & 3,50 & 0,98 \\
\hline Cosmetics Products & 2,77 & 1,04 \\
\hline Cleaning Products & 3,79 & 1,17 \\
\hline
\end{tabular}

Product involvement levels of consumers differ between 1 and 7 . In Table 3, it is seen that the highest involvement level of consumers is toward cleaning products $\left(\mu_{\text {cleaning }}=3,79\right)$. 
Table 4: Factor Analysis for Religiosity

\begin{tabular}{|c|c|c|c|c|c|c|}
\hline & & $\begin{array}{c}\text { Factor } \\
\text { Components }\end{array}$ & $\begin{array}{c}\text { Factor } \\
\text { Loadings } \\
(\%)\end{array}$ & KMO & Bartlett & $\begin{array}{c}\text { Reliability } \\
\text { (Cronbach } \\
\text { Alpha) }\end{array}$ \\
\hline \multirow{12}{*}{ Extrinsic Religiosity } & VAR1 & 0,391 & \multirow{12}{*}{27,394} & \multirow{12}{*}{0,772} & \multirow{12}{*}{0,000} & \multirow{12}{*}{0,754} \\
\hline & VAR2 & 0,301 & & & & \\
\hline & VAR3 & 0,390 & & & & \\
\hline & VAR4 & 0,395 & & & & \\
\hline & VAR5 & 0,052 & & & & \\
\hline & VAR6 & 0,658 & & & & \\
\hline & VAR7 & 0,781 & & & & \\
\hline & VAR8 & 0,635 & & & & \\
\hline & VAR9 & 0,453 & & & & \\
\hline & VAR10 & 0,570 & & & & \\
\hline & VAR11 & 0,389 & & & & \\
\hline & VAR12 & 0,779 & & & & \\
\hline \multirow{9}{*}{ Intrinsic Religiosity } & VAR1 & 0,810 & \multirow{9}{*}{47,947} & \multirow{9}{*}{0,898} & \multirow{9}{*}{0,000} & \multirow{9}{*}{0,871} \\
\hline & VAR2 & 0,759 & & & & \\
\hline & VAR3 & 0,596 & & & & \\
\hline & VAR4 & 0,815 & & & & \\
\hline & VAR5 & 0,786 & & & & \\
\hline & VAR6 & 0,769 & & & & \\
\hline & VAR7 & 0,631 & & & & \\
\hline & VAR8 & 0,133 & & & & \\
\hline & VAR9 & 0,663 & & & & \\
\hline
\end{tabular}

VAR: Variable

Table 4 shows statistics about factor analysis of religiosity. We get two different factors which are intrinsic religiosity and extrinsic religiosity. Extrinsic religiosity factor has 12 variables and intrinsic religiosity factor has 9 variables. KMO and Bartlett sphericity test results show that these variables can be used in factor analysis. Reliability level of the scales can be measured with Cronbach's alpha test. In social sciences, the required level for reliability is 0,7 (Nunnally, 1978). According to the test results both intrinsic and extrinsic religiosity have enough reliability levels $\left(\alpha_{\text {intrinsic }}=\right.$ 0,$\left.871 ; \alpha_{\text {extrinsic }}=0,754\right)$. Consumers' intrinsic religiosity level has greater mean value than extrinsic religiosity level $\left(\mu_{\text {intrinsic }}=3,64 ; \mu_{\text {extrinsic }}=3,02\right)$. 
Table 5: Correlation of Religiosity and Product Involvement Level

\begin{tabular}{|l|l|c|c|c|}
\hline \multicolumn{2}{|c|}{} & Food & Cosmetics & Cleaning \\
\hline \multirow{3}{*}{ Intrinsic Religiosity } & Pearson Correlation & $\mathbf{0 , 2 0 7}$ & $\mathbf{- 0 , 1 3 1}$ & 0,054 \\
\cline { 2 - 5 } & Sig. (2-tailed) & 0,001 & 0,03 & 0,373 \\
\cline { 2 - 5 } & $\mathrm{N}$ & 274 & 275 & 275 \\
\hline \multirow{3}{*}{ Extrinsic Religiosity } & Pearson Correlation & 0,105 & $\mathbf{0 , 1 9 1}$ & $\mathbf{0 , 1 7 2}$ \\
\cline { 2 - 5 } & Sig. (2-tailed) & 0,083 & 0,001 & 0,004 \\
\cline { 2 - 5 } & $\mathrm{N}$ & 274 & 274 & 282 \\
\hline
\end{tabular}

In Table 5, correlation analysis between product involvement level and religious orientation types is shown. According to the results, there is a statistically significant relationship between intrinsic religiosity and food and cosmetics products (significant correlations are shown with bold characters). The relationship with food products is positive and \%20.7; however, relationship with cosmetics products is negative and $\%$ 13.1. As the level of consumers' intrinsic religiosity increases, their involvement against cosmetics products decreases. Extrinsic religiosity has a positive relationship with cosmetics and cleaning products and their ratios are \%19.1 and \%17.2 consequently. With these results $\mathrm{H}_{1}$ and $\mathrm{H}_{2}$ cannot be rejected, hereby there are statistically significant relationships between religious orientation of consumers and their product involvement levels.

Table 6 shows a summary of statistical tests about demographic variables of consumers with product involvement level and religious orientation. The first column shows product involvement, the second column shows the type of religious orientation, in the third column, demographic variable that has a significant statistical relationship with involvement and religiosity is shown. In the fourth column, the type of statistical test applied is seen. The fifth column shows the p-value of the statistical tests in the fourth column. Finally, the last column shows the result of the post-hoc tests.

Table 6: Summary of Statistical Tests

\begin{tabular}{|l|l|l|l|l|l|}
\hline $\begin{array}{l}\text { Product } \\
\text { Involvement }\end{array}$ & $\begin{array}{l}\text { Religious } \\
\text { Orientation }\end{array}$ & $\begin{array}{l}\text { Demographic } \\
\text { Variables }\end{array}$ & Tests & p-value & Post-Hoc \\
\hline \multirow{4}{*}{ Cleaning } & Extrinsic & Education & Welch & 0,045 & Graduate \\
\cline { 2 - 6 } & Extrinsic & Gender & t-test $^{*}$ & 0,024 & Women \\
\cline { 2 - 6 } & Intrinsic & Gender & t-test $^{*}$ & 0,010 & Women \\
\cline { 2 - 6 } & Intrinsic & Occupation & Welch & 0,008 & Health sector \\
\hline Food & Intrinsic & Education & ANOVA & 0,047 & $\begin{array}{l}\text { Primary } \\
\text { school }\end{array}$ \\
\hline Cosmetics & Intrinsic & Occupation & ANOVA & 0,026 & Health sector \\
\hline
\end{tabular}

* Independent Sample t-test

For example, consumers differ according to their education level if they are extrinsically religion oriented and have high involvement level for cleaning product. 
The appropriate statistical test is Welch and its result is 0,045 that is less than 0,05 . According to post-hoc test results, consumers who hold a graduate degree are more involved in cleaning products. As another example, intrinsically-oriented people's involvement level about cleaning products differs according to their gender. Test results show that women are more involved than men in cleaning products. Table 4 shows us that $\mathrm{H}_{3}, \mathrm{H}_{4}, \mathrm{H}_{5}$ cannot be rejected, demographic factors have statistical a significance with both product involvement and religious orientation.

\section{Regression Analysis}

Multiple regressions are used to explore the relationship between one continuous dependent variable and a number of independent variables or predictors. It is recommended that "for social science research, about 15 subjects per predictor are needed for a reliable equation" (Pallant, 2005, pp.140-2). In this model, we have 8 independent variables (intrinsic religiosity, extrinsic religiosity, gender, marital status, age, education level, occupation and monthly household income) so $8 * 15=120$ subjects are needed; nevertheless, we have 282, which is higher than 120.

Table 7: Regression Analysis

\begin{tabular}{|c|c|c|c|c|c|}
\hline Dependent Variable & $\begin{array}{l}\text { Independent } \\
\text { Variables }\end{array}$ & Beta & p-value & VIF & $\mathbf{R}^{2}$ \\
\hline \multirow{3}{*}{$\begin{array}{l}\text { Cosmetics Products } \\
\text { Involvement }\end{array}$} & Extrinsic religiosity & 0,166 & 0,015 & 1,475 & \multirow{3}{*}{0,182} \\
\hline & Intrinsic religiosity & $-0,166$ & 0,011 & 1,338 & \\
\hline & Occupation & 0,282 & 0,000 & 1,120 & \\
\hline \multirow{3}{*}{$\begin{array}{l}\text { Cleaning Products } \\
\text { Involvement }\end{array}$} & Extrinsic religiosity & 0,129 & 0,043 & 1,475 & \multirow{3}{*}{0,075} \\
\hline & Gender & 0,146 & 0,023 & 1,158 & \\
\hline & Education & 0,189 & 0,007 & 1,299 & \\
\hline
\end{tabular}

$\mathrm{R}^{2}$ value shows how much the dependent variable is explained by the model. In Table $5, \mathrm{R}^{2}$ value for cosmetics products involvement is 0,182 , so independent variables in the model explain \%18.2 of variance of dependent variable. For cleaning products involvement $\mathrm{R}^{2}$ is 0,075 , so this model explain $\% 7.5$ of the dependent variable. To assess the statistical significance of the result, $p$-value should be analyzed. This tests the null hypothesis that multiple $\mathrm{R}$ in the population equals to 0 . The model in this example reaches statistical significance (sig. $<0,05$ ). If there is a correlation between independent variables, multicollinearity exists. If the VIF (variance inflation factor) value is above 10, it indicates multicollinearity (Pallant, 2005:150). In Table 5, VIF values of independent variables are not higher than 10 , so it is concluded that there is no multicollinearity.

Beta values show the contribution of independent variables to explain the dependent variable. For example, contribution of extrinsic religiosity to cosmetics product involvement is \%16.6. Intrinsic religiosity level has also same ratio but it is negative. If there is one unit increasing in intrinsic religiosity, it causes 0,166 unit decreases in cosmetics product involvement level.

\section{Conclusion}

Religion is an important part of people's lives. Its effects can be seen in all behaviors of people including purchasing behavior. However, effect of religions on 
marketing discipline has not accurately been held. Involvement is another important concept in marketing. This article investigates the effects of Muslim religiosity on product involvement. The method is a quantitative survey based on a convenience sample of 282 Muslim respondents. Product involvement was measured for three product categories (foods, cosmetics and cleaning products). It is found that extrinsic religiosity has significant effect on product involvement in cleaning products and cosmetics products. In food category, there is no significant effect of extrinsic religiosity. Thus, research hypotheses cannot be falsified in cleaning and cosmetics product category. However, foods product involvement level is affected by consumers' intrinsic religiosity level. When intrinsic religiosity level increases, involvement level about food products also rises. In contrast, involvement level about cosmetics has a negative relationship with intrinsic religiosity. Intrinsically religious consumers think that using cosmetics products violates the rules of their faith. Also, some demographic characteristics such as gender, education level and occupation have significant effects on product involvement for consumers who have both intrinsic and extrinsic religiosity levels. Since consumers' religious orientation affect all their behaviors as well as purchasing behavior, in marketing practices they cannot be ignored. As an important part of culture, religions determine behavior norms and values. In this study, the role of religious orientation on product involvement for three different categories is examined and it is found that different religious orientation has a significant relationship on different product involvement.

The demands of consumers for businesses are beyond everything. When consumers buy a product, they do not only consider advertising or the price, all variables (culture, religion, etc.) important for consumers should be taken into account. Religions have significant limitations on their followers. In this study, only three different product groups are discussed. The most important product category in terms of religious rules is food products. Consumers are more sensitive about religious issues for food products and expect equally the sensitivity of businesses. For example, the contents of the products sold must be clearly stated or halal certificate should be taken in Muslim countries. Although there are religious rules for non-food products, the sensitivity of consumers are not as high. As a result, consumers' values in marketing communication activities should take place in the center.

The relationship between religiosity and marketing concepts do not see required relevancy yet in our country as well as in the world. With this study, it is expected to assist for academics as well as for practitioners in order to know consumers better.

\section{References}

Allport, G, Ross, J. (1967), Personal religious orientation and prejudice, Journal of Personality and Social Psychology, Vol. 2, 423-443.

Assael, Henry, (1998), Consumer Behavior and Marketing Action, 6th Edition, Southwestern College Publishing, USA.

Blackwell, R. D., Miniard, P. W., Engel, J. F. (2006). Consumer behavior (10th ed.). Mason, $\mathrm{OH}$ : Thomson Higher Education. 
Broderick, Amanda J, (2007), A Cross-National Study of the Individual and NationalCultural Nomological Network of Consumer Involvement, Psychology \& Marketing, Vol. 24, No. 4, 343-374.

Delener, Nejdet, (1990), The Effects of Religious Factors on Perceived Risk in Durable Goods Purchase Decisions, The Journal of Consumer Marketing, Vol. 7, No. 3, Summer, 27-38.

Delener, Nejdet, (1994), Religious Contrasts in Consumer Decision Behavior Patterns: Their Dimensions and Marketing Implications, European Journal of Marketing, Vol. 28, No. 5, 36-53.

Dholakia, Utpal M, (2000), A motivational process model of product involvement and consumer risk perception, European Journal of Marketing, Vol. 35, No. 11, 13401360 .

Essoo, N, Dibb, S, (2004), Religious Influences on Shopping Behavior: An Exploratory Study, Journal of Marketing Management, Vol. 20, 683-712.

George, B, Edward, M, (2009), Cognitive Dissonance and Purchase Involvement in the Consumer Behavior Context, The IUP Journal of Marketing Management, Vol. 8, No. 3, 7-24.

Higgie, A.R, Feick F.L, (1989), Enduring Involvement: Conceptual and Measurement Issues, Advances in Consumer Research, Vol. 16, 690-696.

King, J.E, Crowther, M.R, (2004), The measurement of religiosity and spirituality: Examples and issues from psychology, Journal of Organizational Change Management, Vol. 17, No. 1, 83-101.

Laurent, G, Kapferer, J.N, (1985), Measuring Consumer Involvement Profiles, Journal of Marketing Research, Vol. 22, February, 41-53.

Lindridge, Andrew, (2005), Religiosity and the construction of a cultural-consumption identity, Journal of Consumer Marketing, Vol. 22, no. 3, 142-151.

Michaelidou, N, Dibb S, (2008), Consumer involvement: a new perspective, The Marketing Review, Vol. 8, No. 1, 83-99.

Mittal, Banwari, (1989), Measuring Purchase-Decision Involvement, Psychology \& Marketing, Vol. 6, No. 2, Summer, 147-162.

Mokhlis, Safiek, (2006), The effect of Religiosity on shopping orientation: An exploratory study in Malaysia, Journal of American Academy of Business, Vol.9, No.1, 64-74.

Mokhlis, Safiek, (2009), Relevancy and Measurement of Religiosity in Consumer Behavior Research, International Business Research, Vol. 2, No. 3, July, 75-84.

Muhamad, N, Mizerski, D, (2010), The constructs mediating religions' influence on buyers and consumers, Journal of Islamic Marketing, Vol. 1, No. 2, 124-135.

Nunnally, J., (1978), Psychometric Theory, $2^{\text {nd }}$ edition, New York, McGraw-Hill.

Onay, Ahmet, (2004), Dindarlık, Etkileşim ve Değişim, Dem Yayınları, İstanbul.

Pallant, Julie, (2005), SPSS Survival Manual A step by step guide to data analysis using SPSS for Windows (Version12), $2^{\text {nd }}$ edition, Allen \& Unwin, Australia. 
Saeed, M, Ahmed Z.U, Mukhtar S-M, (2001), International Marketing Ethics from an Islamic Perspective: A Value-Maximization Approach, Journal of Business Ethics, Vol. 32, No. 2, July, 127-142.

Sheth, J.N, Mittal B, (2004), Customer Behavior: A Managerial Perspective, 2nd ed. Mason, OH: Thomson South-Western.

Swimberghe, K, Sharma, D, Flurry L, (2009), An exploratory investigation of the consumer religious commitment and its influence on store loyalty and consumer complaint intentions, Journal of Consumer Marketing, Vol. 26, No. 5, 340-347.

Venkatraman, M.P, (1989), Involvement and Risk, Psychology \& Marketing, Vol. 6, No.3, 229-247.

Vitell, S.J, Paolillo J.G.P, Singh J.J, (2005), Religiosity and Consumer Ethics, Journal of Business Ethics, Vol. 57, 175-181.

Zaichkowsky, Judith L, (1985), Measuring the Involvement Construct, Journal of Consumer Research, Vol. 12, December, 341-352.

Zaichkowsky, Judith L, (1986), Conceptualizing Involvement, Journal of Advertising, Vol. 15, No. 2, 4-15. 